\title{
Pythium and Phytopythium Species in Two Pennsylvania Greenhouse Irrigation Water Tanks
}

Carla E. Choudhary, Maria L. Burgos-Garay, and Gary W. Moorman, Department of Plant Pathology \& Environmental Microbiology, The Pennsylvania State University, University Park 16802; and Chuanxue Hong, Virginia Polytechnic Institute and State University, Hampton Roads Agricultural Research and Extension Center, Virginia Beach 23455

\begin{abstract}
Choudhary, C. E., Burgos-Garay, M. L., Moorman, G. W., and Hong, C. 2016. Pythium and Phytopythium species in two Pennsylvania greenhouse irrigation water tanks. Plant Dis. 100:926-932.

Two commercial greenhouses producing potted plants in Pennsylvania using recycled irrigation water in an ebb-and-flood system have incurred significant crop losses due to Pythium aphanidermatum. In cooperation with the greenhouses, one or more of their water tanks was monitored continuously (128 tank samplings) for Pythium spp. by baiting. Nine species of Pythium and three species of Phytopythium were recovered, representing clades A, B, E, and $\mathrm{K}$, but none was $P$. aphanidermatum. The recovered Pythium spp. were (i) P. rostratifingens, (ii) isolates identical to Pythium sp. nov. OOMYA1702-08 (clade B2), (iii) $P$. coloratum, (iv) P. middletonii,

(v) and (vi) two new species in clade E2, (vii) a new species in clade B2, (viii) isolates very similar to Pythium sp. nov. OOMYA1646-08 (clade E2), and (ix) a new species in clade A. The Phytopythium spp. recovered were (i) Phytopythium litorale, (ii) P. helicoides, and (iii) P. chamaehyphon. This article illustrates the different communities of Pythium and Phytopythium spp. found in each greenhouse over 10 months. Some of the baited species display resistance to the oomycete fungicide active ingredient, mefenoxam. $P$. helicoides and the new species in clade B2 were pathogenic on seedlings in potting mix with fertilizer added.
\end{abstract}

Due to the awareness of the environmental impacts of fertilizer runoff from agricultural systems, some state governments have mandated the use of recycled irrigation water in commercial greenhouses (Hong and Moorman 2005). An added benefit to these mandates is conserving water in plant production but this benefit comes at a cost. Plant pathogens, including zoosporic species in the genus Pythium, may spread throughout the crop via the recycled water (Agrios 2005; Bush et al. 2003; Ivors and Moorman 2014).

Pythium, from the Greek "pythein"- to cause rot (Anonymous 2014) - is a genus of organisms in the class Oomycota and kingdom Chromalveolata (Beakes et al. 2012). Some species of Pythium, especially Pythium aphanidermatum (Edson) Fitzp., $P$. ultimum Trow, $P$. irregulare Buisman, and P. cryptoirregulare (Garzón, Yánez, \& G. W. Moorman), are plant pathogens and have the potential to cause significant losses of greenhouse crops (Moorman et al. 2002). Pythium spp. are generally thought to be harbored in or dispersed via irrigation water (van der Plaats-Niterink 1981), largely due to the zoosporic phase of their lifecycle (Ivors and Moorman 2014). Thus monitoring of irrigation water for Pythium spp. may provide knowledge needed to manage a Pythium disease outbreak (Fisher and Smith 2007). Recently, it was discovered and confirmed that the species

Corresponding author: G. W. Moorman; E-mail: gmoorman@psu.edu

This project was funded by the National Institute of Food and Agriculture, United States Department of Agriculture (USDA), Specialty Crops Research Initiative Grant under award number 2010-51181-21140 (Integrated management of zoosporic pathogens and irrigation water quality for a sustainable green industry).

Any opinions, findings, conclusions or recommendations expressed in this publication are those of the authors and do not necessarily reflect the view of the USDA.

GenBank ascension numbers KT247386-KT247408.

TreeBase submission ID 17766

Accepted for publication 18 November 2015

http://dx.doi.org/10.1094/PDIS-07-15-0836-RE

(C) 2016 The American Phytopathological Society in clade $\mathrm{K}$ of Pythium, following the clade categories of Lévesque and de Cock (2004), are genetically quite distinct from the rest of the genus. Species in this grouping have been given the new genus name Phytopythium (Baten et al. 2014; de Cock et al. 2015). Phytopythium helicoides is a problematic pathogen in greenhouses that use ebb-and-flood watering systems (Kageyama et al. 2002; Takahashi et al. 2014).

Many research reports note the presence of plant pathogens, including oomycetes, in water (Hong et al. 2014). Pythium spp. have been baited from freshwater sources (Abdelzaher et al. 1994; Al-Sheikh and Hani 2012; Nechwatal et al. 2008; Shrestha et al. 2013) and Pythium spp. were found in a survey of the water that enters a Colorado greenhouse, but not species responsible for causing crop losses (Pottorff and Panter 1997). A large number of Pythium spp. were found in a Virginia container nursery's irrigation system (Bush et al. 2003). Pythium irregulare was discovered in an irrigation water sample submitted to the Plant Disease Clinic at Penn State (Moorman et al. 2002). Phytopythium litorale was frequently baited from vegetable irrigation ponds in Georgia, and was pathogenic on squash (Parkunan and Ji 2013). An extensive literature review reported 14 species and three groups of Pythium to be present in ebb-and-flood or hydroponic systems (Hong et al. 2014).

Some species of Pythium are found commonly associated with water. Pythium aphanidermatum is found in Pythium clade A, which contains other species pathogenic to marine algae. Clade B contains species with noninflated, filamentous sporangia (Lévesque and de Cock 2004); group F according to the system of van der PlaatsNiterink (van der Plaats-Niterink 1981). In a study of Pythium spp. in hydroponic systems, clade B species were most commonly found and $P$. aphanidermatum represented only $5 \%$ of the species found (Gull et al. 2004). Both clade A and B contain waterborne Pythium spp., and representatives from both clades have been isolated from a lake (Al-Sheikh and Hani 2012). Four new Pythium spp. belonging to clade B have been found in Japanese freshwater (Uzuhashi et al. 2015). Overall, it appears that clade A species other than $P$. aphanidermatum and clade B species are found more often than $P$. aphanidermatum in water (Gull et al. 2004; Nechwatal and Mendgen 2009; Shrestha et al. 2013). These commonly found species are not important plant pathogens and may only cause diseases on a certain crop or under particular environmental conditions (van der Plaats-Niterink 1981).

In the present work, water monitoring was conducted in cooperation with two commercial greenhouses in Pennsylvania that recycle irrigation water during the production of potted floricultural crops 
and where, in previous years, crop losses had resulted from disease initiated by Pythium spp. (Burgos-Garay 2013), particularly P. aphanidermatum. The objective of the work was to identify and biologically characterize the community of Pythium spp. that exist in the irrigation tanks of these Pennsylvania greenhouses and to determine whether irrigation water in those greenhouses is a significant source of $P$. aphanidermatum.

\section{Materials and Methods}

The two commercial greenhouses in Pennsylvania cooperating in this research produce plants all year. Greenhouses S (less than 1 ha under glass) and E (approximately 6.5 ha under glass) have similar production practices, starting crops from their own cuttings or seedlings or from rooted and unrooted cuttings or seedlings purchased from other greenhouses, and are approximately 50 miles apart by air in central Pennsylvania. Bench ebb-and-flood irrigation systems are used in E and cement floor ebb-and-flood is used in both greenhouses to irrigate crops, collect excess water, and return it to the tanks for use in the next irrigation cycle. The water tanks are filled from onsite wells. The excess irrigation water is passed through a screen or fabric to remove coarse particulate matter before it returns to the tank. Both greenhouses grow bedding plants, potted chrysanthemum, and poinsettia as major crops. Various water-soluble fertilizers are added to the irrigation water.
Continuous baiting of the tanks was conducted as described previously (Burgos-Garay 2013). Briefly, blades of creeping bentgrass (Agrostis stolonifera L. 'Penn Eagle') were placed between pieces of fiberglass screen and positioned in the recycling irrigation water tanks when the tanks were in active use. Water temperatures in each tank were recorded continuously (HOBO Water Temp Pro v2 sensors; Onset Computer Corp., Bourne, MA). The 7-day water temperature average for each tank is noted in Table 1. Continuous baiting was conducted for 27 weeks (March to June and September to December 2011) of one tank (designated $C$ ) in greenhouse $S$ and in one to four tanks (designated L, 32 weeks; R, 33 weeks; SB, 15 weeks; and G, 21 weeks) in greenhouse E (March to December 2011) for a total of 128 baiting periods. Two bait holders were deployed per tank. One was attached to an anchor at the bottom (designated B) of the tank (>3 $\mathrm{m}$ in depth) along with the temperature sensor and the other was loosely attached to the anchor rope by a ring that allowed the bait holder to always float at the water surface (designated T) in the tank. After being deployed for 7 days, the bait holders were sent by the grower via overnight express to the laboratory, and fresh leaf blades were deployed. Blades were plated on NARF (clarified 20\% V8 juice agar [V8] amended with nystatin, ampicillin, rifampicin, and fluazinam; Campbell's Soup Co., Camden, NJ) (Morita and Tojo 2007 ) in 60-by- $15 \mathrm{~mm}$ petri plates. Plates were incubated in the dark at $21^{\circ} \mathrm{C}$. Mycelium was transferred into new NARF plates to obtain a

Table 1. Average water temperature over a 7-day period ending on the sampling date in 2011 (Date) in recycling ebb-and-flood irrigation tanks located inside two commercial greenhouses $^{\mathrm{a}}$

\begin{tabular}{|c|c|c|c|c|c|c|}
\hline \multirow[b]{2}{*}{ Date } & \multicolumn{4}{|c|}{ Greenhouse $\mathbf{E}$ temperature $\left({ }^{\circ} \mathrm{C}\right)$} & \multicolumn{2}{|c|}{ Greenhouse $\mathbf{S}$} \\
\hline & Tank L & Tank R & Tank G & Tank S & Date & Tank $\mathbf{C}\left({ }^{\circ} \mathrm{C}\right)$ \\
\hline 22 March & 16.14 & 19.85 & $\ldots$ & $\ldots$ & $22 \mathrm{March}$ & 18.90 \\
\hline $28 \mathrm{March}$ & 15.96 & 19.54 & $\ldots$ & $\ldots$ & $28 \mathrm{March}$ & 20.47 \\
\hline 4 April & 15.55 & 19.25 & $\ldots$ & $\ldots$ & 5 April & 20.37 \\
\hline 11 April & 15.84 & 20.28 & $\cdots$ & $\cdots$ & 11 April & 20.25 \\
\hline 18 April & 15.98 & 20.43 & $\ldots$ & $\ldots$ & 18 April & 20.13 \\
\hline 25 April & 16.38 & 19.73 & $\ldots$ & $\ldots$ & 25 April & 20.20 \\
\hline 2 May & 16.02 & 21.29 & $\ldots$ & $\ldots$ & 2 May & 20.97 \\
\hline 9 May & 16.21 & 20.06 & $\ldots$ & $\ldots$ & 9 May & 20.38 \\
\hline 18 May & $\ldots$ & 22.16 & $\ldots$ & $\ldots$ & 16 May & 22.42 \\
\hline 26 May & $\ldots$ & 23.31 & $\ldots$ & $\ldots$ & 25 May & 22.45 \\
\hline 1 June & $\ldots$ & 26.49 & $\ldots$ & $\ldots$ & 31 May & 25.17 \\
\hline 8 June & $\ldots$ & 25.57 & $\ldots$ & $\ldots$ & 6 June & 25.12 \\
\hline 16 June & Missing data & 25.61 & $\ldots$ & $\ldots$ & $\ldots$ & $\ldots$ \\
\hline 23 June & Missing data & 25.33 & 26.12 & $\ldots$ & $\ldots$ & $\ldots$ \\
\hline 1 July & $\ldots$ & 26.29 & 27.22 & $\ldots$ & $\ldots$ & $\ldots$ \\
\hline 8 July & 16.33 & 26.82 & $\ldots$ & 25.95 & $\ldots$ & $\ldots$ \\
\hline 14 July & 18.95 & 22.64 & 26.25 & 29.31 & $\ldots$ & $\ldots$ \\
\hline 20 July & 18.28 & 22.47 & 26.27 & 29.83 & $\ldots$ & $\ldots$ \\
\hline 27 July & 18.50 & 25.91 & 26.49 & 31.44 & $\ldots$ & $\ldots$ \\
\hline 2 August & 21.18 & 25.85 & 26.80 & 27.20 & $\ldots$ & $\ldots$ \\
\hline 9 August & 23.17 & 26.77 & 26.85 & 25.59 & $\ldots$ & $\ldots$ \\
\hline 16 August & 20.52 & $\ldots$ & 26.65 & $\ldots$ & $\ldots$ & $\ldots$ \\
\hline 22 August & 20.22 & $\ldots$ & 26.65 & $\ldots$ & $\ldots$ & $\ldots$ \\
\hline 30 August & 22.25 & $\ldots$ & $\ldots$ & $\ldots$ & $\ldots$ & $\ldots$ \\
\hline 13 September & 22.75 & $\ldots$ & $\ldots$ & $\ldots$ & 16 September & 24.03 \\
\hline 20 September & 18.02 & 20.33 & 22.20 & $\ldots$ & 22 September & 22.56 \\
\hline 27 September & 17.66 & 22.07 & 23.17 & $\ldots$ & 26 September & 21.82 \\
\hline 4 October & 18.62 & 22.91 & 20.90 & $\ldots$ & 4 October & 21.82 \\
\hline 12 October & 19.35 & 21.95 & 20.41 & 20.82 & 20 October & 21.20 \\
\hline 18 October & 19.25 & 20.77 & Missing data & 21.19 & 18 October & 20.21 \\
\hline 24 October & 18.36 & 19.34 & 20.81 & 20.77 & 25 October & 20.09 \\
\hline 31 October & 18.03 & 18.55 & 20.15 & 19.55 & 1 October & 20.18 \\
\hline 7 November & 18.29 & 17.86 & 19.88 & 18.37 & 8 November & 19.84 \\
\hline 14 November & 18.83 & 17.42 & 20.36 & 18.41 & 15 November & 19.28 \\
\hline 21 November & 18.73 & 17.22 & 20.24 & 18.53 & 22 November & 19.21 \\
\hline 29 November & 18.67 & 17.75 & 20.09 & 17.65 & 29 November & 19.22 \\
\hline \multirow[t]{3}{*}{6 December } & 18.44 & 17.40 & 19.64 & 16.37 & 6 December & 19.20 \\
\hline & $\ldots$ & $\ldots$ & $\ldots$ & $\ldots$ & 13 December & 18.14 \\
\hline & $\ldots$ & $\ldots$ & $\ldots$ & $\ldots$ & 20 December & 17.84 \\
\hline
\end{tabular}

\footnotetext{
${ }^{a}$ Symbol: ... indicates times when the tanks were not in use.
} 
pure culture and to water agar for initial microscopic observations. During initial observations, a single hyphal tip was cut and used to continue the culture.

Fungicide resistance was determined for mefenoxam (Subdue MAXX; 21.3\% mefenoxam; Syngenta, Greensboro, NC) using a poison-plate method (Moorman et al. 2002). Pythium cultures were maintained on potato dextrose agar (PDA). In the poison-plate tests, $20 \% \mathrm{~V} 8$ agar $(100 \mathrm{ml}$ of clarified V8 diluted in $400 \mathrm{ml}$ of distilled water) was used as the control agar. The experimental agar was $20 \%$ V8 agar amended with a discriminating concentration of mefenoxam at $100 \mu \mathrm{g} / \mathrm{ml}$. A cork borer ( $5.5 \mathrm{~mm}$ in diameter) was used to remove mycelial plugs from a young PDA culture. A plug was placed on each of two plates ( $60 \mathrm{~mm}$ in diameter) of V8 agar free of fungicide and two plates of V8 agar amended with mefenoxam. The date and time of transfer were recorded and the plates were incubated in the dark at $25^{\circ} \mathrm{C}$. Following a $24-\mathrm{h}$ incubation, the edge of the inoculum block and the edge of the mycelium was marked along two arbitrary radii. The distance between the marks was measured using Sylvac digital calipers (Sylvac, Crissier, Switzerland) and automatically entered into the computer spreadsheet using Gage Wedge software (TAL Technologies, Inc., Philadelphia). The average growth rates per hour were calculated and the percent growth rate on the fungicide plates as compared with growth on fungicide-free agar was calculated. If this number was below $40 \%$ then the isolate was considered sensitive to the fungicide, as previously described (Burgos-Garay 2013; Moorman et al. 2002) while isolates whose growth was 40 to $60 \%$ were categorized as intermediate, and isolates whose growth on amended agar was greater than $60 \%$ as compared with growth on nonamended agar were categorized as mefenoxam resistant. This experiment was repeated two times per isolate and repeated more than two times if both results were not similar.

In order to identify isolates, DNA sequencing was employed. For amplification of the internal transcribed spacer (ITS) region (ITS1, 5.8, and ITS2), the universal primers ITS1 (5'-TCCGTAGGT GAACCTGCGG-3') and ITS4 (5' TCCTCCGCTTATTGATAGC-3') were used. The cytochrome oxidase (cox) gene was amplified using FM 59 (TTTATGGTCAATGTAGTGAAA) and FM 55 (GGCATAC CAGCTAAACCTAA) (Burgos-Garay 2013). The polymerase chain reaction (PCR) master mix used to carry out the ITS direct PCR reactions contained $2 \mu l$ of $(10 \times)$ PCR buffer, $0.5 \mu l$ of dNTP $(10 \mathrm{mM})$, $1 \mu \mathrm{l}$ each of ITS1 and ITS4 (5 mM), $15.4 \mu \mathrm{l}$ of sterile distilled water, and $0.1 \mu \mathrm{l}$ of Taq polymerase, totaling $20 \mu \mathrm{l}$ in each reaction tube. Colonies on NARF agar were gently scraped with a pipette tip and swirled into the reaction tubes. The thermocycling protocol, electrophoresis, and DNA visualization is described in Burgos-Garay (2013). Region cox I and II amplification followed the methods of Garzón et al. (2007). Cycling parameters were those described by Martin (2000). DNA sequences were edited using Sequencher (version 5.4.1 sequence analysis software, Gene Codes Corporation).

Once the forward and reverse sequences were obtained and edited, the sequences were compared with those in the databases The National Center for Biotechnology Information Basic Local Alignment Search Tool (Johnson et al. 2008) and The Barcode of Life Data System (BOLD) (Ratnasingham and Hebert 2007). The sequences were aligned using the G-INS-I option of MAFFT v7.147.b (Katoh and Standley 2013). The genes were concatenated using SequenceMatrix (Vaidya et al. 2011). The maximum-likelihood and 1,000 bootstrap analyses for both individual genes and concatenated trees were performed using the CIPRES Science Gateway (Miller et al. 2010) tool "Genetic Algorithm for Rapid Likelihood Inference" (GARLI 2.01 on XSEDE), which uses the general time reversible model of nucleotide substitution and performs heuristic phylogenetic searches. Consensus trees were made using the CIPRES tool "Consense". The results were converted into Phylip format using the CIPRES tool "NCLconverter" and opened in the program Molecular Evolutionary Genetics Analysis, version 6 (Tamura et al. 2013). To further examine isolates that did not match any known species, two more analyses using the same methods were performed to confirm that they are probably new species (new species analysis unpublished). This was made possible by including sequences from the isolates obtained by baiting with the sequences of all other species in their respective clade. The clade system of Lévesque and de Cock (2004) was followed. If the percent similarity value was below $98 \%$ for either ITS or cox, then the isolate was categorized as a new species. A polyphasic approach that integrated the DNA with biological and morphological characteristics was utilized to make a clear species delineation (morphological data not shown.)

The pathogenicity of selected representative isolates was tested using Pelargonium $\times$ hortorum 'White Orbit' or 'Maverick White' geranium seedlings. White-flowered cultivars tend to be more susceptible to disease (Panjehkeh et al. 2007), making these varieties good model host plants to employ. Five seeds were placed on sterile filter paper moistened with $15 \mathrm{ml}$ of $300-\mathrm{ppm}$ nitrogen watersoluble fertilizer $\left(15 \% \mathrm{~N}, 15 \% \mathrm{P}_{2} \mathrm{O}_{5}\right.$, and $15 \% \mathrm{~K}_{2} \mathrm{O}$; Peters Professional; The Scotts Company LLC, Marysville, $\mathrm{OH}$ ) in plastic food containers with a slightly raised central area. The containers were placed under fluorescent growth lights with a 12-h day-and-night cycle at room temperature. After a week of growth, the seedlings were inoculated. Isolates were grown on water agar with $101-\mathrm{cm}-$ long segments of creeping bentgrass (A. stolonifera L. Penn Eagle) blades that had been boiled for $10 \mathrm{~min}$ in distilled water. After 3 days of incubation in the dark at $25^{\circ} \mathrm{C}$, a grass blade colonized by the isolate was placed on the root of the seedling. Two containers were set up for each isolate and the experiment was repeated. The experiment was set up in a randomized block design. The positive controls were $P$. aphanidermatum (P128; originally isolated from chrysanthemum in greenhouse $\mathrm{E}$ in 2003), P. irregulare (P84; originally isolated from a hydroponic production system in a commercial greenhouse in 2001), and $P$. cryptoirregulare (P123; originally isolated from impatiens in greenhouse $\mathrm{E}$ in 2003). First symptoms were usually observed 1 to 2 days after inoculation. The temperatures were recorded for each test (StowAway; Onset Computer).

Pathogenicity was also tested in potting mix in the laboratory as follows. Fafard number 2 (Conrad Fafard, Inc., Agawam, MA) potting mix was steam pasteurized for $60 \mathrm{~min}$. Approximated $75 \mathrm{ml}$ of this mix was placed in each 4.7-cm (2.25-in.) square plastic flower pot. Five Pelargonium $\times$ hortorum Maverick White geranium seeds were planted at the perimeter of each pot and watered thoroughly. The pots were placed in an opaque, black plastic flat, covered with a clear plastic dome, and another opaque black plastic flat was inverted over the clear dome in order to foster good seed germination. After $48 \mathrm{~h}$, the inverted flat was removed and the dome-covered flat of potted seedlings was placed under fluorescent lights (12-h day-and-night cycle) at room temperature $\left(20\right.$ to $\left.22^{\circ} \mathrm{C}\right)$ in the laboratory. The potted plants were fertilized with 300-ppm nitrogen water-soluble fertilizer $\left(15 \% \mathrm{~N}, 15 \% \mathrm{P}_{2} \mathrm{O}_{5}\right.$, and $15 \% \mathrm{~K}_{2} \mathrm{O}$; Peters Professional; The Scotts Company LLC). Autoclaved rye (Secale cereale L.) seed were sprinkled on the surface of water agar. While one plate of rye seed was not inoculated, each isolate to be tested was inoculated onto the center of other plates containing rye seed. The plates were incubated at room temperature for approximately 7 days. Approximately 7 days after seeding, pots with five seedlings were chosen or seedlings from extra pots were transplanted to obtain five seedlings per pot. In the center of each pot, a glass rod ( $7 \mathrm{~mm}$ in diameter) was used to make a hole to the bottom of the pot. Two incubated, noninoculated rye seeds were placed in the hole of each control pot and two colonized seeds were place in the hole of each pot of inoculated plants, and all of the pots were watered lightly with fertilizer-containing water. Five noninoculated control pots and five inoculated pots per test isolate were incubated at room temperature under the fluorescent lights in one laboratory and an additional five control pots and five pots per test isolate were incubated in another laboratory. In addition to the noninoculated control plants, P. aphanidermatum isolates P128 and P220 (originally isolated from tomato plants grown in a commercial greenhouse hydroponic system in 2014) were included as standard comparisons. The number of infected seedlings in each pot was recorded.

Isolates were also tested in two greenhouse experiments. In the first experiment, greenhouse temperatures ranged from 14 to $20^{\circ} \mathrm{C}$, with a mean temperature of $17.6^{\circ} \mathrm{C}$ in November and $15.5^{\circ} \mathrm{C}$ in December. In the second experiment, the temperatures ranged from 
15 to $30^{\circ} \mathrm{C}$, with averages of $18.8^{\circ} \mathrm{C}$ in March, $20.9^{\circ} \mathrm{C}$ in April, and $22.8^{\circ} \mathrm{C}$ in May. Inoculum was grown on PDA for a week at $25^{\circ} \mathrm{C}$ in the dark, then homogenized with sterile distilled water $(100 \mathrm{ml}$ of sterile water per 100 -by-15-mm plate). Homogenate $(10 \mathrm{ml})$ was placed on the potting soil (Fafard number 2) surface in round plastic pots (10 $\mathrm{cm}$ in diameter), each containing one 6-week-old geranium. There were 30 pots each for $P$. aphanidermatum, $P$. irregulare, $P$. cryptoirregulare, and the control. Selected isolates obtained during the greenhouse irrigation tank baiting were inoculated in 10 pots/isolate. The experimental design was completely random across three greenhouse benches. After the experiment, the height of every plant was measured and analyzed using the Sidak method and Bonferroni method in a general linear model analysis of variance (ANOVA) in SAS (Rodriguez 2011). After the experiment, plant roots were removed to determine whether the inoculated isolate remained on the plant roots. Five 2-cm-long root segments were placed on water agar in order to isolate Pythium or Phytopythium spp. This was done on two plants each per replicate, except for the negative controls and the positive control plants with the highly virulent species. For those treatments, roots from five plants were harvested and plated for each experiment. Isolate identification was done by sequencing the ITS region.

\section{Results}

Species obtained by baiting in this study are presented in Figure 1 (in gray), along with their closest matches from the BOLD database (Ratnasingham and Hebert 2007). In total, nine Pythium and three Phytopythium spp. representing clades A, B, E, and K (Table 2) were discovered, but $P$. aphanidermatum was not found in any tank. The Pythium spp. found during the tank baiting were (i) P. rostratifingens, (ii) isolates identical to Pythium sp. nov. OOMYA1702-08 in clade B2, (iii) P. coloratum, (iv) P. middletonii, (v) and (vi) two distinct new species in clade E2, (vii) a new species in clade B2, (viii) isolates very similar to Pythium sp. nov. OOMYA1646-08 in clade E2, and (ix) a new species in clade A. The Phytopythium

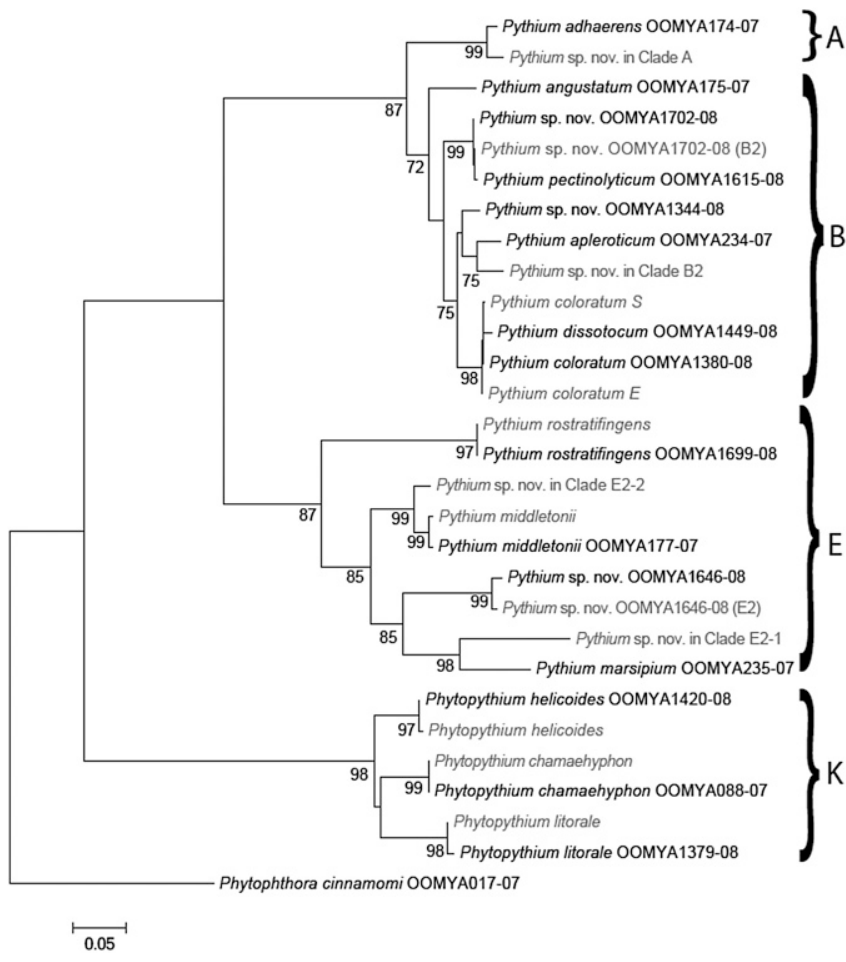

Fig. 1. Maximum-likelihood analysis (1,000 bootstraps) of a concatenated gene tree of the internal transcribed spacer and cytochrome oxidase I regions of a representative isolate of each Pythium and Phytopythium from recycling ebb-and-flood irrigation water in two commercial greenhouses. A, B, E, and $\mathrm{K}$ clade groupings according to Lévesque and de Cock (2004); OOMYA labeled isolate sequences from Robideau et al. (2011) that most closely match isolates obtained in the present work in gray. spp. recovered were (i) Phytopythium litorale, (ii) P. helicoides, and (iii) $P$. chamaehyphon. The following isolates have been deposited in the CBS Fungal Biodiversity Centre: Pythium sp. nov. (S9.26.11.CB [clade A]), CBS accession number 140047; Pythium sp. nov. (E10.31.11RT similar to OOMYA1646-08 [clade E2]), CBS accession number 140048; Pythium sp. nov. (E6.16.11LT [clade E2-1]), CBS accession number 140049; Pythium sp. nov. (E10.4.11LT [clade E2-2]), CBS accession number 140050; Pythium sp. nov. (E7.14.11SBB [clade B2]), CBS accession number 140051; and Pythium middletonii (E8.30.11LT), CBS accession number 140052.

The number of nucleotide differences in the ITS and cox DNA regions from their closest match on BOLD is shown in Table 2. It is apparent that the species we confidently identified had few nucleotide differences and that the putative new species have a greater number of nucleotide differences from their closest relative. Measurements of the cardinal temperatures of growth, and sizes and positions of oogoinia, hyphae, sporangia, zoospores, antheridia, and discharge tubes of isolates that we identified as known species, were within the ranges of those known species reported in the literature (data not shown). Isolates of Phytopythium litorale and the isolate identical to Pythium sp. nov. OOMYA1702-08 (clade B2) were quickly lost in culture and, therefore, did not receive any morphological characterization.

The percentage of the sampling dates that isolates of each species were recovered during baiting is shown in Figures 2 and 3. Pythium sp. nov. in clade E2-1, Pythium coloratum, Pythium sp. nov. in clade E2-2, isolates very similar to Pythium sp. nov. OOMYA1646-08 (clade E2), and Pythium sp. nov. in clade A isolates were found in tanks in both of the greenhouses. All isolates obtained by baiting are in clades A, B, E, and $\mathrm{K}$ and species from each clade were found in both greenhouses. In greenhouse E, Pythium sp. nov. in clade E2-1, Pythium sp. nov. in clade B2, and Phytopythium helicoides were recovered most frequently; whereas, in greenhouse S, Pythium coloratum was recovered most frequently. The number of isolates that were baited from each greenhouse during each month of sampling is illustrated in Figures 4 and 5. Phytopythium helicoides was obtained during the baiting only from greenhouse E, often in July but also in June and August. An isolate identical to Pythium sp. nov. OOMYA 1702-08 (clade B2) was only baited one time from greenhouse E in March. Pythium sp. nov. in clade E2-1 was baited from greenhouse E in June, July, and August and from greenhouse $\mathrm{S}$ in September. Pythium coloratum was frequently baited in greenhouse E from March to August and from greenhouse S throughout the sampling time (March to June and October to December.) Pythium sp. nov. in clade E2-2 was recovered from greenhouse E in July and October and in greenhouse $\mathrm{S}$ in September. P. middletonii

Table 2. Number of nucleotide differences in the internal transcribed spacer (ITS) and cytochrome oxidase (cox) DNA regions of Pythium and Phytopythium isolates from recycling ebb-and-flood irrigation water in two commercial greenhouses as compared with their closest relative in The Barcode of Life Data System (Ratnasingham and Hebert 2007)

\begin{tabular}{|c|c|c|c|}
\hline \multirow[b]{2}{*}{ Isolate designation } & \multirow{2}{*}{$\begin{array}{l}\text { Number of } \\
\text { isolates }\end{array}$} & \multicolumn{2}{|c|}{$\begin{array}{l}\text { Nucleotide } \\
\text { differences }\end{array}$} \\
\hline & & ITS & $\operatorname{cox}$ \\
\hline Pythium sp. nov. in clade E2-1 & 3 & 77 & 49 \\
\hline Pythium coloratum & 37 & 0 & 2 \\
\hline Pythium sp. nov. in clade E2-2 & 6 & 32 & 13 \\
\hline Pythium middletonii & 1 & 0 & 8 \\
\hline Pythium sp. nov. in clade B2 & 4 & 25 & 27 \\
\hline $\begin{array}{l}\text { Isolates very similar to Pythium sp. } \\
\text { nov. OOMYA1646-08 (clade E2) }\end{array}$ & 6 & 1 & 13 \\
\hline Pythium rostratifingens & 3 & 0 & 0 \\
\hline Pythium sp. nov. in clade A & 4 & 6 & 18 \\
\hline $\begin{array}{l}\text { Isolates identical to Pythium sp. nov. } \\
\text { OOMYA1702-08 }\end{array}$ & 1 & 2 & 1 \\
\hline Phytopythium chamaehyphon & 7 & 0 & 0 \\
\hline Phytopythium helicoides & 9 & 3 & 2 \\
\hline Phytopythium litorale & 1 & 0 & 2 \\
\hline
\end{tabular}


Greenhouse E species isolations

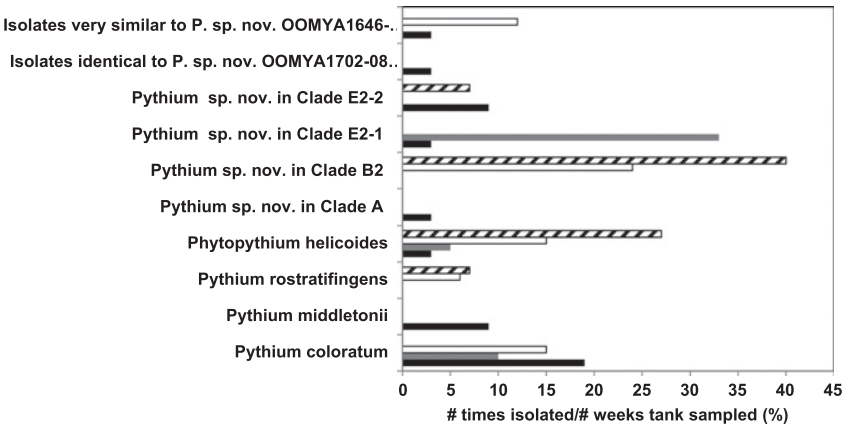

Fig. 2. Number of times Pythium and Phytopythium spp. were isolated from four recycling ebb-and-flood irrigation water tanks in commercial greenhouse $E$ per number of samplings, expressed as a percentage: striped bar $=$ tank $S$, open bar $=\operatorname{tank} R$, gray bar $=\operatorname{tank} G$, and solid bar $=\operatorname{tank} \mathrm{L}$.

\section{Greenhouse S species isolations}

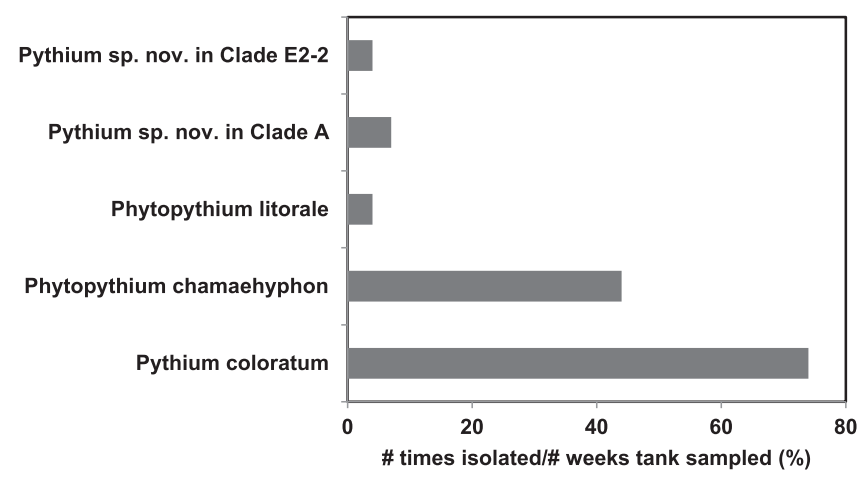

Fig. 3. Number of times Pythium and Phytopythium spp. were isolated from a recycling ebb-and-flood irrigation water tank in commercial greenhouse $S$ per number of samplings, expressed as a percentage. was isolated only from greenhouse $\mathrm{E}$ in September. Isolates of Pythium sp. nov. in clade B2 were found frequently in greenhouse E in May to August. Isolates identical to Pythium sp. nov. OOMYA 1646-08 (clade E2) was found in greenhouse E in November and December and in greenhouse $\mathrm{S}$ in December. P. rostratifingens was baited from greenhouse $\mathrm{E}$ in November and December. Pythium sp. nov. in clade A was baited from greenhouse $\mathrm{E}$ in April and greenhouse S in May, September 2011 and 2013. Phytopythium litorale was baited once from greenhouse $\mathrm{S}$ in March. Pythium chamaehyphon was baited from greenhouse $S$ in September to December. Tank temperatures throughout the experiment are provided in Table 1.

Results of the mefenoxam resistance in vitro test are shown in Table 3. Isolates of Pythium sp. nov. in clade E2-1 were sensitive to mefenoxam. $P$. coloratum isolates varied in reaction to mefenoxam, having at least one isolate in each category. Phytopythium helicoides isolates displayed an intermediate response. Most Pythium sp. nov. in clade E2-2 were sensitive to mefenoxam, with one isolate being intermediate. The one isolate of Pythium middletonii was resistant. Isolates of Pythium sp. nov. in clade B2 were sensitive to mefenoxam. Most of the isolates very similar to Pythium sp. nov. OOMYA1646-08 (clade E2) were mefanoxam resistant, with one being sensitive. The $P$. rostratifingens isolates were resistant. Some Phytopythium chamaehyphon isolates were sensitive while others were intermediate in sensitivity. Isolates of Pythium sp. nov. in clade A were mefenoxam resistant.

In the laboratory pathogenicity test using fertilizer-moistened filter paper (Table 4), some of the isolates identified as Pythium sp. nov. in clade E2-1, Pythium coloratum, Pythium sp. nov. in clade E2-2, Pythium sp. nov. in clade B2, and Phytopythium chamaehyphon were pathogenic while others were nonpathogenic. In the cases of $P$. helicoides and Pythium sp. nov. in clade A, some isolates were pathogenic. Pythium rostratifingens isolates were nonpathogenic. Symptoms generally appeared approximately 1 to 2 days after inoculation.

The laboratory potting mix pathogenicity tests included two isolate representatives from baited species. P. middletonii, Phytopythium helicoides, and Pythium sp. nov. in clade B2 caused visible symptoms, while Pythium aphanidermatum (standard isolate P220) consistently caused seedling mortality. Symptoms as a result of P220 inoculation generally appeared 4 days after inoculation but sometimes were apparent after 2 days, and the maximum number of plants dying was reached

\section{Greenhouse E Isolates}

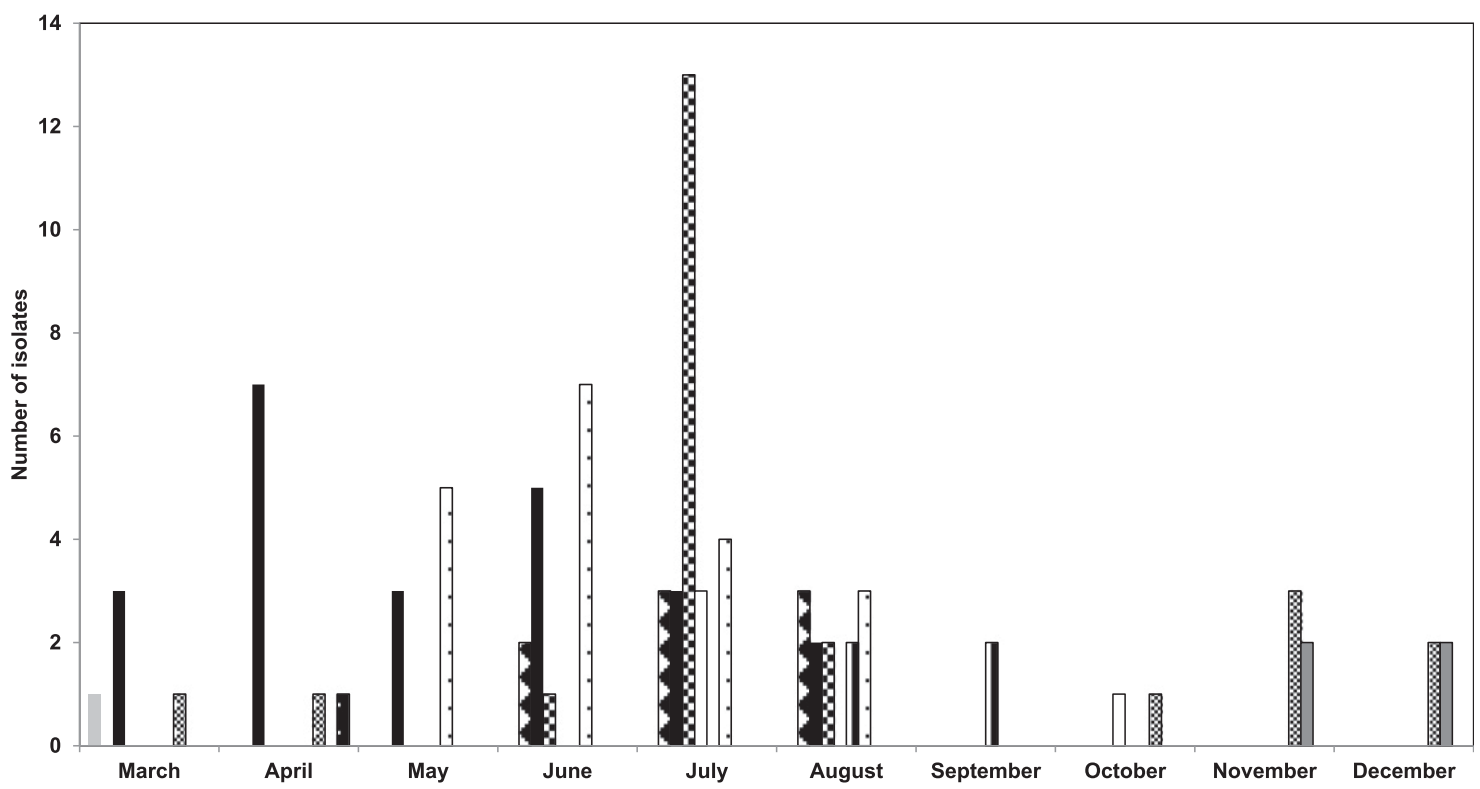

Fig. 4. Pythium and Phytopythium spp. from recycling ebb-and-flood irrigation water in commercial greenhouse $\mathrm{E}$, displayed by the number of isolates obtained per month. Bars: light gray $=$ isolates identical to Pythium sp. Nov. OOMYA1702-08 (clade B2), checkerboard $=$ Pythium sp. nov. in clade E2-1 R, black $=$ Pythium coloratum, diamonds $=$ Phytopythium helicoides, white $=$ Pythium sp. nov. in clade E2-2, vertical striped $=$ Pythium middletonii, white with black dots $=$ Pythium sp. nov. in clade B2, gray with white dots $=$ isolates very similar to Pythium sp. nov. OOMYA1646-08 (clade E2), solid gray $=P$. rostratifingens, and black with white dots Pythium sp. nov. in clade A. 
by day seven or eight. P128 P. aphanidermatum did not consistently cause disease.

None of the plants exhibited symptoms in either greenhouse experiment. The heights of each group were compared using the Sidak method and Bonferroni method in a general linear model ANOVA $(P \leq 0.05)$, and no significant differences were found among the treatments. All of the isolates used in these greenhouse experiments that had been obtained by baiting were recovered from the plant roots at the end of the greenhouse experiments, whereas P220 and P128 were not recovered from roots.

\section{Discussion}

Each of the two cooperating greenhouses has a characteristic community of Pythium or Phytopythium spp.; however, some of the species were found in both greenhouses. Only isolates from clades A, B, $\mathrm{E}$, and $\mathrm{K}$ were found. In a lake survey in Germany, Pythium isolates from clades $\mathrm{A}, \mathrm{B}$, and $\mathrm{K}$ were found, in addition to some from clades $\mathrm{J}$ and $\mathrm{F}$ (Nechwatal et al. 2008).

$P$. aphanidermatum is known to have caused crop losses in the two cooperating greenhouses in seasons prior to this study. However, $P$. aphanidermatum was not detected during the 128 samplings. The Pennsylvania Plant Disease Clinic received samples with $P$. aphanidermatum from both greenhouses during the time we were sampling but losses were incidental and not economically significant (data not shown). Although it is possible that the creeping bentgrass baiting used here was not ideal for detecting P. aphanidermatum, this method has been used successfully to capture $P$. aphanidermatum from an aquatic source (Al-Sheikh and Hani 2012), and P. aphanidermatum is a pathogen of turfgrass (Allen et al. 2004). We conclude that recycled irrigation water is not a significant source of $P$. aphanidermatum in the two commercial greenhouses monitored during their production of potted plants.

Most of the isolates obtained are not regarded as major pathogens in greenhouse crops. However, all of the species we isolated, except for Phytopythium chamaehyphon and Pythium rostratifingens, have been reported to cause plant diseases in other laboratory tests. Some of these cases appear to be quite temperature dependent (Baptista et al. 2011; Kageyama et al. 2002; Parkunan and Ji 2013; Petkowski et al. 2013; Weiland et al. 2013). P. coloratum is pathogenic on some root crops (El-Tarabily et al. 1996; Vincelli and Lorbeer 1990). The lab test we employed using fertilizer-moistened filter paper is a very simplified environment for Pythium disease development. The seedlings were 1 week old, the filter paper was constantly moist, the roots were exposed directly to the inoculum, and the microbial community in the system was probably very small and not very diverse. We found pathogenic isolates in most groups obtained, except $P$. rostratifingens, which is concordant with the literature (de Cock and Lévesque 2004). To our knowledge, this is the first report of Phytopythium chamaehyphon being classified as pathogenic in any system. We suspect that an environment more like the

Table 3. Number of Pythium and Phytopythium isolates from recycling ebband-flood irrigation water in two commercial greenhouses categorized as sensitive (S), intermediate (I), or resistant $(\mathrm{R})$ to mefenoxam based on in vitro growth on clarified V8 juice agar amended with mefenoxam at $100 \mu \mathrm{g} / \mathrm{ml}^{\mathrm{a}}$

\begin{tabular}{lrcc}
\hline Isolate designation (number of isolates tested) & S & I & R \\
\hline Pythium sp. nov. in clade E2-1 (4) & 4 & $\ldots$ & $\ldots$ \\
Pythium coloratum (39) & 25 & 5 & 9 \\
Phytopythium helicoides (9) & $\ldots$ & 9 & $\ldots$ \\
Pythium sp. nov. in clade E2-2 (6) & 5 & 1 & $\ldots$ \\
Pythium middletonii (1) & $\ldots$ & $\ldots$ & 1 \\
Clade B2 unknown (5) & 4 & 1 & $\ldots$ \\
Isolates very similar to Pythium sp. nov. & 1 & $\ldots$ & 5 \\
OOMYA1646-08 (clade E2) (6) & & & \\
Pythium rostratifingens (3) & $\ldots$ & $\ldots$ & 3 \\
Phytopythium chamaehyphon (7) & 3 & 4 & $\ldots$ \\
Pythium sp. nov. in clade A (5) & $\ldots$ & $\ldots$ & 5 \\
\hline
\end{tabular}

${ }^{a} \mathrm{~S}=$ growth was less than $40 \%$ of that on mefenoxam-free agar, I = growth was 40 to $60 \%$ of that on mefenoxam-free agar, and $\mathrm{R}=$ growth was more than $60 \%$ of that on mefenoxam-free agar.

Table 4. Pathogenicity of Pythium and Phytopythium isolates from recycling ebb-and-flood irrigation water in two commercial greenhouses to Pelargonium $\times$ hortorum seedlings grown on filter paper or in soilless potting mix in the laboratory ${ }^{\mathrm{a}}$

\begin{tabular}{lcc}
\hline Isolate designation & Filter paper & Potting mix \\
\hline Pythium sp. nov. in clade E2-1 & -+ & - \\
Pythium coloratum & -+ & - \\
Phytopythium helicoides & + & + \\
Pythium sp. nov. in clade E2-2 & -+ & - \\
Pythium sp. nov. in clade B2 & -+ & + \\
Pythium rostratifingens & - & - \\
Phytopythium chamaehyphon & -+ & - \\
Pythium sp. nov. in clade A & + & - \\
Pythium middletonii & Not tested & + \\
Isolates similar to Pythium sp. nov. & Not tested & - \\
OOMYA1646-08 (E2) & &
\end{tabular}

a Symbols: - + indicates that some isolates did not kill a majority of seedlings in each test and other isolates did kill a majority of seedlings, - indicates that no isolate killed a majority of seedlings in each test, and + indicates that all isolates killed a majority of seedlings in each test.

\section{Greenhouse S Isolates}

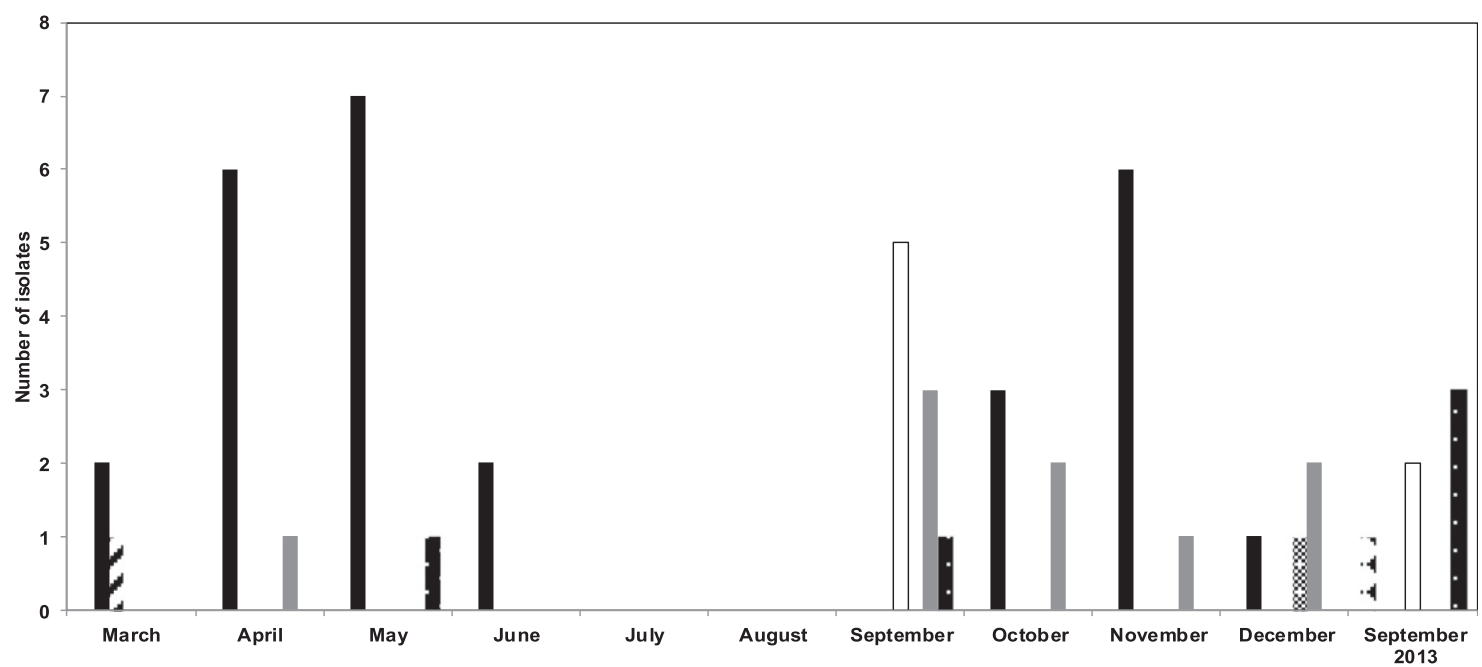

Fig. 5. Pythium and Phytopythium spp. from recycling ebb-and-flood irrigation water in commercial greenhouse $\mathrm{S}$, displayed by the number of isolates obtained per month Bars: diamonds = Pythium sp. nov. in Clade E2-1 R, black = Pythium coloratum, slanted stripes $=$ Phytopythium litorale, white = Pythium sp. nov. in clade E2-2, gray with white dots $=$ isolates very similar to Pythium sp. nov. OOMYA1646-08 (clade E2), solid gray = Phytopythium chamaehyphon, and black with white dots $=$ Pythium sp. nov. in clade A. 
filter paper pathogenicity tests, such as a hydroponic production, could experience seedling losses to some of the isolates of Pythium and Phytopythium we obtained. When isolate pathogenicity was tested using 1-week-old seedlings in pasteurized, peat-based potting mix irrigated with fertilizer, $P$. helicoides, Pythium middletonii, and Pythium sp. nov. in clade B2 caused disease symptoms. Phytopythium helicoides has been reported as a greenhouse pathogen (Kageyama et al. 2002); therefore, growers face a possible risk from this species in their water.

In the greenhouse experiment, the positive control (Pythium aphanidermatum P128, a known plant-pathogenic species) did not cause disease. It is possible that the temperatures were not conducive to disease, or P128 had been kept in culture too long and lost pathogenicity. The loss of pathogenicity in fungi is common (Dahmen 1983) but, to our knowledge, has not been reported in the literature for Pythium spp. It is interesting to note that, although isolates obtained from the greenhouse water samplings did not cause disease, they were consistently associated with roots. Further work is required to determine their possible roles there.

None of the isolates baited from the recycled irrigation water in the present experiments have been found causing crop losses in samples submitted to the Penn State Plant Disease Clinic from the greenhouses cooperating in this study or from any other greenhouses (G. Moorman, unpublished data). However, some of the baited isolates are mefenoxam resistant, suggesting that the use of fungicides may have been a selection pressure on the total oomycete community. Consideration should be given to the possibility that nonpathogenic or weakly pathogenic oomycete species frequently found in water may serve as a reservoir of fungicide resistance that could be transferred to plant-pathogenic species (Nechwatal and Mendgen 2009).

\section{Acknowledgments}

We thank J. Edson and S. Getson for their technical contributions to this project and D. Geiser for his input on the phylogenetic analyses.

\section{Literature Cited}

Abdelzaher, H. M. A., Ichitani, T., and Elnaghy, M. A. 1994. Pythium marsipium from pond water in Osaka. Mycol. Res. 98:920-922.

Agrios, G. N. 2005. Plant Pathology, 5th ed. Academic Press, San Diego, CA

Allen, T. W., Martinez, A., and Burpee, L. L. 2004. Pythium blight of turfgrass. Online publication. Plant Health Instruct. doi:10.1094/PHI-I-2004-0929-01

Al-Sheikh, H., and Hani, M. A. A. 2012. Occurrence, identification and pathogenicity of Pythium aphanidermatum, P. diclinum, P. dissotocum and Pythium "Group P" isolated from Dawmat Al-Jandal Lake, Saudi Arabia. Res. J. Environ. Sci. 6:196-209.

Anonymous. 2014. Pythium. Merriam-Webster. Merriam-Webster.com http://www. merriam-webster.com/dictionary/pythium

Baptista, F. R., Pires-Zottarelli, C. L. A., Teixeira, L. D., and dos Santos, N. A., Jr. 2011. Avaliação patogênica in vitro de Pythium middletonii Sparrow e Pythium dissotocum Drechsler em alface. (In vitro pathogenic evaluation of Pythium middletonii Sparrow and Pythium dissotocum Drechsler in lettuce.) Summa Phytopathol. 37:52-58.

Baten, M. A., Asano, T., Motohashi, K., Ishiguro, Y., Rahman, M. Z., Inaba, S., Suga, H., and Kageyama, K. 2014. Phylogenetic relationships among Phytopythium species, and re-evaluation of Phytopythium fagopyri comb. nov., recovered from damped-off buckwheat seedlings in Japan. Mycol. Prog. 13:1003.

Beakes, G. W., Glockling, S. L., and Sekimoto, S. 2012. The evolutionary phylogeny of the oomycete "fungi". Protoplasma 249:3-19.

Burgos-Garay, M. L. 2013. Effect of heterotrophic bacterial communities on Pythium spp. in recycled irrigation water. Ph.D. dissertation, The Pennsylvania State University.

Bush, E. A., Hong, C., and Stromberg, E. L. 2003. Fluctuations of Phytophthora and Pythium spp. in components of a recycling irrigation system. Plant Dis. 87: 1500-1506.

Dahmen, H. 1983. Technique for long-term preservation of phytopathogenic fungi in liquid nitrogen. Phytopathology 73:241-246.

de Cock, A. W. A. M., and Lévesque, C. A. 2004. New species of Pythium and Phytophthora. Stud. Mycol. 50:481-487.

de Cock, A. W. A. M., Lodhi, A. M., Rintoul, T. L., Bala, K., Robideau, G. P., Abad, Z. G., Coffey, M. D., Shahzad, S., and Lévesque, C. A. 2015. Phytopythium: Molecular phylogeny and systematics. Persoonia 34:25-39.

El-Tarabily, K. A., Hardy, G., and Sivasithamparam, K. 1996. Association of Pythium coloratum and Pythium sulcatum with cavity spot disease of carrots in western Australia. Plant Pathol. 45:727-735.

Fisher, P., and Smith, C. 2007. Monitoring pathogens and algae. Greenhouse Grower. Mid-September 2007:1-3.

Garzón, C. D., Yánez, J. M., and Moorman, G. W. 2007. Pythium cryptoirregulare, a new species within the P. irregulare complex. Mycologia 99:291-301.
Gull, C., Labuschagne, N., and Botha, W. J. 2004. Pythium species associated with wilt and root rot of hydroponically grown crops in South America. Afr. Plant Prot. 10:109-116.

Hong, C., Moorman, G., Wohanka, W., and Büttner, C. 2014. Biology, Detection, and Management of Plant Pathogens in Irrigation Water. American Phytopathological Society, St. Paul, MN.

Hong, C. X., and Moorman, G. W. 2005. Plant pathogens in irrigation water: Challenges and opportunities. Crit. Rev. Plant Sci. 24:189-208.

Ivors, K. L., and Moorman, G. W. 2014. Oomycete plant pathogens in irrigation water. Pages 57-64 in: Biology, Detection, and Management of Plant Pathogens in Irrigation Water. C. Hong, G. Moorman, W. Wohanka, and C. Büttner, eds. American Phytopathological Society, St. Paul, MN.

Johnson, M., Zaretskaya, I., Raytselis, Y., Merezhuk, Y., McGinnis, S., and Madden, T. L. 2008. NCBI BLAST: A better web interface. Nucleic Acids Res. 36:W5-W9.

Kageyama, K., Aoyagi, T., Sunouchi, R., and Fukui, H. 2002. Root rot of miniature roses caused by Pythium helicoides. J. Gen. Plant Pathol. 68:15-20.

Katoh, K., and Standley, D. M. 2013. MAFFT multiple sequence alignment software version 7: Improvements in performance and usability. Mol. Biol. Evol. 30:772-780.

Lévesque, C. A., and de Cock, A. W. A. M. 2004. Molecular phylogeny and taxonomy of the genus Pythium. Mycol. Res. 108:1363-1383.

Martin, F. N. 2000. Phylogenetic relationships among some Pythium species inferred from sequence analysis of the mitochondrially encoded cytochrome oxidase II gene. Mycologia 92:711-727.

Miller, M. A., Miller, M. A., Pfeiffer, W., Pfeiffer, W., Schwartz, T., and Schwartz, T 2010. Creating the CIPRES science gateway for inference of large phylogenetic trees. Pages 1-8 in: Gateway Computing Environments Workshop, New Orleans, LA. IEEE Access.

Moorman, G. W., Kang, S., Geiser, D. M., and Kim, S. H. 2002. Identification and characterization of Pythium species associated with greenhouse floral crops in Pennsylvania. Plant Dis. 86:1227-1231.

Morita, Y., and Tojo, M. 2007. Modifications of PARP medium using fluazinam, miconazole, and nystatin for detection of Pythium spp. in soil. Plant Dis. 91:1591-1599.

Nechwatal, J., and Mendgen, K. 2009. Evidence for the occurrence of natural hybridization in reed-associated Pythium species. Plant Pathol. 58:261-270.

Nechwatal, J., Wielgoss, A., and Mendgen, K. 2008. Diversity, host, and habita specificity of oomycete communities in declining reed stands (Phragmites australis) of a large freshwater lake. Mycol. Res. 112:689-696.

Panjehkeh, N., Backhouse, D., and Taji, A. 2007. Flower colour is associated with susceptibility to disease in the legume Swainsona formosa. Australas. Plant Pathol. 36:341-346.

Parkunan, V., and Ji, P. S. 2013. Isolation of Pythium litorale from irrigation ponds used for vegetable production and its pathogenicity on squash. Can. J. Plant Pathol. 35:415-423.

Petkowski, J. E., de Boer, R. F., Norng, S., Thomson, F., and Minchinton, E. J. 2013 Pythium species associated with root rot complex in winter-grown parsnip and parsley crops in south eastern Australia. Australas. Plant Pathol. 42:403-411.

Pottorff, L. P., and Panter, K. L. 1997. Survey of Pythium and Phytophthora spp. in irrigation water used by Colorado commercial greenhouses. HortTechnology 7:153-155.

Ratnasingham, S., and Hebert, P. D. N. 2007. BOLD: The Barcode of Life Data System (www.barcodinglife.org). Mol. Ecol. Notes 7:355-364.

Robideau, G. P., de Cock, A. W. A. M., Coffey, M. D., Voglmayr, H., Brouwer, H., Bala, K., Chitty, D. W., Désaulniers, N., Eggertson, Q. A., Gachon, C. M. M., Hu, C.-H., Küpper, F. C., Rintoul, T. L., Sarhan, E., Verstappen, E. C. P., Zhang, Y., Bonants, P. J. M., Ristaino, J. B., and Lévesque, C. A 2011. DNA barcoding of oomycetes with cytochrome c oxidase subunit I and internal transcribed spacer. Mol. Ecol. Resour. 11:1002-1011.

Rodriguez, R. N. 2011. SAS. Wiley Interdiscip. Rev. Comput. Stat. 3:1-11. Sequencher version 5.4.1 sequence analysis software, Gene Codes Corporation, Ann Arbor, MI. http://www.genecodes.com

Shrestha, S. K., Zhou, Y., and Lamour, K. 2013. Oomycetes baited from streams in Tennessee 2010-2012. Mycologia 105:1516-1523.

Takahashi, R., Fukuta, S., Kuroyanagi, S., Miyake, N., Nagai, H., Kageyama, K. and Ishiguro, Y. 2014. Development and application of a loop-mediated isothermal amplification assay for rapid detection of Pythium helicoides. FEMS Microbiol. Lett. 355:28-35

Tamura, K., Stecher, G., Peterson, D., Filipski, A., and Kumar, S. 2013. MEGA6 Molecular Evolutionary Genetics Analysis version 6.0. Mol. Biol. Evol. 30: 2725-2729.

Uzuhashi, S., Okada, G., and Ohkuma, M. 2015. Four new Pythium species from aquatic environments in Japan. Antonie Leeuwenhoek 107:375-391.

Vaidya, G., Lohman, D. J., and Meier, R. 2011. SequenceMatrix: Concatenation software for the fast assembly of multi-gene datasets with character set and codon information. Cladistics 27:171-180.

van der Plaats-Niterink, A. J. 1981. Monograph of the Genus Pythium Centraalbureau voor Schimmelcultures, Baarn, The Netherlands.

Vincelli, P. C., and Lorbeer, J. W. 1990. Root-rot of onion caused by Pythium irregulare and Pythium coloratum. Mycopathologia 111:67-72.

Weiland, J. E., Beck, B. R., and Davis, A. 2013. Pathogenicity and virulence of Pythium species obtained from forest nursery soils on Douglas-fir seedlings. Plant Dis. 97:744-748. 